\title{
REMARKS ON THE MEANINGS OF RUSSIAN VERBS
}

\author{
Iwao YAMAGUCHI (Kyoto Univ.)
}

\section{FUNDAMENTAL HYPOTHESIS CONCERNING THE MEANING OF VERBS}

$\S 1$. In our conception, difference in part of speech corresponds in principle to the difference in the manner of cognition at the level of formation of lexical meaning rather than directly to the lexical meaning itself. A. A. Shakhmatov, too, seems to have shared the same conception when he said, that "a noun is a part of speech corresponding, in the first place, to the notion of substance, and in the second, to the notion of quality or actionstate, which are conceived of as having no connection with the notion of bearer or actor." (Italics by I. Y.).) It is regrettable that the epistemological bases of his definition of a part of speech have not been given due consideration.

$\S 2$. If we take this assumption for granted, the question we must answer next is in what consist characteristic traits peculiar to the meaning of verbs in general.

If we take, for example, a typical expression denoting a physical action such as "to cut down a tree", we have a situation, in which there exist at least a "man", an "axe" and a "tree". The positional relationships of these objects one to the other are such that a "man" has an "axe" in his hand and stands in front of a "tree". Then the hand moves repeatedly upwards and downwards or to the left and to the right, so that the "axe" strikes the "tree" at a certain

1. Из трудов А. А. Шахматова по современному русскому языку. Учение о частях речи. М., 1965, cited by Suprun. A. Е. Супрун: Части речи в русском языке. М., 1971, p.32. 
place until the "tree" is finally divided into two. If the "division" is not realized, it would not be a case of "cutting down". Instead it would be conceived of simply "striking" the tree, or, if the "axe" does not actually make contact with the "tree", as merely "swinging" the axe at the tree.

$\S 3$. It follows from this observation, that one and the same "action" may be conceived of as different "actions" depending upon the presence or absence of certain conditions. In other words, we choose a set of conditions from the outer, extralinguistic reality and, so to speak, stylize them into a pattern and apprehend, that there was, is, or will be an "action".

Thus, we cannot but come to the conclusion, that a physical, concrete "action" such as "to cut down" is, despite our firm conviction to the contrary, no more visible to our eyes than mental "actions" like "to think" etc., because "actions" denoted by verbs do not exist but on the level of language. That is, when we use language we perceive a set of relevant change of situations in conformity with existing patterns of "action" and recognize, that there did, do, or will take place this very "action".

\section{SEMANTIC STRUCTURE OF VERBS}

$\S 4$. As to the relevant change of situations which constitute the content of an utterance, it is hardly probable that the change occurs in every constituent of the situation. Perceiving an action, the speaker's attention is usually concentrated on the change in state of a special object and, if necessary, on that of subsidiary object ( $c f$. change in state of a "tree" cited above.), excluding all of the other changes as irrelevent. We will denote state of the object in question $x$ by $S_{x}$ and change in its state by $\mathrm{dS}_{\mathrm{x}}{ }^{2}$ )

$\S 5$. However, it is not always sufficient to specify an "action" in terms of changes of situations alone: generally speaking, a set of additional conditions should be taken into account ( $c f$. "to run" and "to walk" etc.). We will denote this set of additional conditions by $\mathrm{K}$.

It follows from the analysis given above, that the meaning of a verb is

2. I. Yamaguchi: A Consideration of the Category of Transitivity in Russian. The Humanities. the Bulletin of Faculty of Liberal Arts, Kyoto University. 1974, pp.44-54. 
made of groups of features heterogeneous to each other.

\section{TRANSITIVE, INTRANSITIVE AND QUASITRANSITIVE VERBS}

$\S 6$. Now, we are able to define transitivity and intransitivity as follows.

D0. An action is called intransitive when a change in state of an object $\mathrm{x}$, together with a set of additional conditions, is sufficient by itself for determining an action; and transitive, when another change of state is needed beside that of the main object $x$.

In other words, we perceive an "int ransitive action" through a set of terms $\mathrm{dS}_{\mathrm{x}}$ and $\mathrm{K}$, and a "transitive action" through that of terms $\mathrm{dS}_{\mathbf{x}}, \mathrm{dS} \mathrm{S}_{\mathbf{y}}$ and $\mathrm{K}$. We will denote these "actions" by the formulae:

F1. V (itr.): $\left[\mathrm{d} \mathrm{S}_{\mathrm{x}}, \mathrm{K}\right]$

F2. V(tr.): $\left[\mathrm{d} \mathrm{S}_{\mathrm{x}}, \mathrm{dS} \mathrm{S}_{\mathrm{y}}, \mathrm{K}\right]$

It must be pointed out, that definition DO is free from concepts like "actor" or "patient" of an action.

$\S 7$. It immediately follows from DO, that:

D1. the accusative complement denotes a subsidiary object, change in state of which is necessary for specifying a particular action as such.

This definition is, it is true, well suited to such cases as рубить дерево "to cut down a tree", взорвать скалу "to blow up a rock" etc., but it is not appropriate to explain such cases аs видеть гору "to see a mountain", or читать книгу "to read a book", because in these cases the object denoted by complement remains unaffected during the action denoted by these verbs. Thus it becomes evident that D1 is too narrow to explain these examples.

These circumstances made us propose a broader definition:

D2. An accusative complement also denotes the object, presence of which is considered as a necessary condition for specifying a particular action.

According to this definition the accusative complement may not always denote the recipient of change of state.

Thus, it is clear, that accusative complements of the D2-class are included 
in those of the D1-class but not vice versa.

We will call verbs which require D2-class complements quasitransitives. Their meanings can be described as follows:

F3. $V($ qtr. $):\left[\mathrm{dS}_{\mathrm{x}}, \mathrm{S}_{\mathrm{y}}, \mathrm{K}\right]^{3)}$

\section{STATIVE VERBS}

$\S 8$. In our opinion, the meanings of stative verbs are characterized by the absence of change of situation in time and, therefore, may seem to be described as follows on the analogy of meanings of quasitransitives:

$$
\begin{aligned}
& * \mathrm{~V} \text { (itr. stat.): }\left[\mathrm{S}_{\mathrm{x}}, \mathrm{K}\right] \\
& * \mathrm{~V} \text { (tr. stat.): }\left[\mathrm{S}_{\mathrm{x}}, \mathrm{S}_{\mathrm{y}}, \mathrm{K}\right]
\end{aligned}
$$

However, in contradistinction to quasitransitives which presuppose change of state in the object $\mathrm{x}$, there is no reason why stative verbs in above mentioned semantic description must be conceived of as verbs and not as adjectives, for example.

In view of these circumstances, we proposed to introduce a notion of time into the definition of meaning of stative verbs to avoid this theoretical difficulty. i.e.

F4. V (itr. stat.): $\left[S_{x},\left(S_{x}\left(t_{0}\right)=S_{x}\left(t_{1}\right)\right) \cdot K\right]$

F5. V (qtr. stat.): $\left[S_{x}, S_{y},\left(R\left(S_{x}\left(t_{0}\right), S_{y}\left(t_{0}\right)\right)=\right.\right.$

$$
\left.\left(\mathrm{R}\left(\mathrm{S}_{\mathrm{x}}\left(\mathrm{t}_{1}\right), \mathrm{S}_{\mathrm{y}}\left(\mathrm{t}_{1}\right)\right)\right) \cdot \mathrm{K}\right]
$$

where the notation $S_{x}\left(t_{0}\right)=S_{x}\left(t_{1}\right) \cdot K$ means that the state of $x$ at the point of time $t_{0}$ is equal to that of $x$ at $t_{1}$, and this condition is included in the set of additional conditions $K$, while $\left(R\left(S_{x}\left(t_{0}\right), S_{y}\left(t_{0}\right)\right)=R\left(S_{x}\left(t_{1}\right)\right.\right.$, $\left.S_{y}\left(t_{1}\right)\right)$ ) means, that the relation between the state of $x$ and that of $y$ at $t_{0}$ equals the relation between them at $t_{1}{ }^{4}$ )

Stative verbs can only be, from our epistemological point of view, quasitransitives, because change of state in y does not occur.

§ 9. Russian verbs like вьрть-ти, кыпъти, кысъти, скрипғти еtс. have

3. I. Yamaguchi: Quasitransitive verbs. BJAR (Bulletin of the Japanese Association of Russists) No.8. Tokyo, 1976, pp.1-12.

4. I. Yamaguchi: Stative verbs. SPP (Studia Philologica Palaeoussica) XII, 1978, pp.57-62. 
the same suffix of state inherited from I.E. as in the case of most stative verbs. We will call them stative verbs of relative constancy (stativa non per se).

The meanings of this kind of verbs have a characteristic trait in common which consists in the following: in a interval of time $\left[t_{0}, t_{1}\right]$ there exists a series of points of time $t_{0}=t_{1}^{\prime}, t_{2}^{\prime}, \ldots t_{n-1}^{\prime}, t_{n}^{\prime}=t$ such that $S_{x}\left(t_{1}^{\prime}\right)=$ $S_{x}\left(t_{2}^{\prime}\right)=\ldots=S_{x}\left(t_{n-1}^{\prime}\right)=S_{x}\left(t_{n}^{\prime}\right)$ or $R\left(S_{x}\left(t_{1}^{\prime}\right), S_{y}\left(t_{1}^{\prime}\right)\right)=R\left(S_{x}\left(t_{2}^{\prime}\right), S_{y}\left(t_{2}^{\prime}\right)\right)=$ $\ldots R\left(S_{x}\left(t_{n-1}^{\prime}\right), S_{y}\left(t_{n-1}^{\prime}\right)\right)=R\left(S_{x}\left(t_{n}^{\prime}\right), S_{y}\left(t_{n}^{\prime}\right)\right)$. If we use notations, for the convenience of description, $\operatorname{Rep} .\left(S_{x}\right)$ and $\operatorname{Rep} .\left(R\left(S_{x}, S_{y}\right)\right)$ respectively, then, semantic structure of these verbs can be described as follows:

F6. V (itr. stat. nps): $\left[\mathrm{dS}_{\mathrm{x}},\left(\operatorname{Rep} .\left(\mathrm{S}_{\mathrm{x}}\right)\right) \cdot \mathrm{K}\right]$

F7. $V\left(\right.$ tr. stat. nps): $\left[\mathrm{dS}_{\mathrm{x}}, \mathrm{d} \mathrm{S}_{\mathrm{y}},\left(\operatorname{Rep} .\left(\mathrm{R}\left(\mathrm{S}_{\mathrm{x}} \mathrm{S}_{\mathrm{y}}\right)\right)\right) \cdot \mathrm{K}\right]$

\section{INCOMPLETE VERBS}

$\S 10$. From the observation on the meaning of incomplete verbs in Old Russian we came to the conclusion that incomplete intransitives require a complement denoting a notion of state or class $\mathrm{P}$ which is an indispensable constituent of the meaning of this class of verbs: in this case, an additional condition is incorporated in $\mathrm{K}$ indicating, from our point of view, that the state of an object $x$ is to be changed into $P$, or $x$ is to be made to belong to class $P$ as its element. Hence the semantic description of these verbs will be:

F8. V (itr. incom.): $\left[\mathrm{dS}_{\mathrm{x}}, \mathrm{P},\left(\mathrm{S}_{\mathrm{x}} \rightarrow \mathrm{P}\right) \cdot \mathrm{K}\right]^{5)}$

Syntactically the notion $\mathrm{P}$ is expressed by a nominative complement which traditional grammarians call "the second nominative" (второй именительный).

To this kind of verbs belong, first of all, verba fiendi: for example,

E1. Онъ же нын ворогъ ми ся учиниль.

"Now he has become my enemy (nom.)" (Hypat. Chr.).

$\S 11$. The notion $\mathbf{P}$ can be indicated in another way. In this case we have so called "inchoatives". Such is the case with verbs like pъдъти, бъльти etc.. These verbs can be interpreted as a result, obtained by putting a

5. I. Yamaguchi: The Second Accusatives in Old Russian. The Humanities, No.23, 1977 , pp.73-86. 
constant expressed by the verb-stem in substitution for a variable $\mathbf{P}$ in the formula F8:

F9. V (itr. inch.): $\left[\mathrm{dS}_{\mathrm{x}},\left(\mathrm{S}_{\mathrm{x}} \rightarrow p\right) \cdot \mathrm{K}\right]$

$\S 12$. Verbum existentiae быть can also be counted among verbs of the F8-class ( $c f$. *bheuə-“to become”) except for its present forms:

E2. Посемь же перея власть его всю Ярославъ, и басть самовластець Русьстьй земли.

“... and he became a despotic ruler (nom.) of the Russian country." (Laur. Chr.).

E3. и да посъ-чени будуть мечи своими, оть стръл и оть иного оружья своего, и да будуm рабы въ весь въ-къ в будущий.

“. . . and they may become slaves (nom.)" (Laur. Chr.).

$\S 13$. Incomplete transitive verbs have meanings paralel to those of incomplete intransitives.

F10. V (tr. incom.): $\left[\mathrm{dS}_{\mathrm{x}}, \mathrm{dS} \mathrm{y}, \mathrm{Q},\left(\mathrm{S}_{\mathrm{y}} \rightarrow \mathrm{Q}\right) \cdot \mathrm{K}\right]$ where $\mathrm{Q}$ is a notion of state or class comparable to $\mathrm{P}$ in $\mathbf{F} 8$ with the difference that the former is expressed by the so-called "second accusative" (второй винительный). The difference in notation here is merely to avoid confusion of grammatical cases. To this class of verbs belong verba faciendi and verba capiendi. e.g.

E4. ....и поставиша архиепископа Новоугородоу Феоктиста. “... and they nominated Theoctistus for the position of Novgorodian archbishop". (1. Nov. Chr.).

E5. Добръ зъло послхъ сынъ твои Георгии, его же створи Господь нампстника по тобъ твоему владычьству.

“. . . George, whom the Lord made your successor to your episcopate." (Ilarion).

E6. Святополкь поя соб жену пщерь Тугорканю князя Половецьскаго.

"Svyatopolk took as his wife a daughter of Tugorkhan, the king of Polovets"' (Hypat. Chr.).

$\S 14$. As for incomplete quasitransitives, their meanings cannot have the condition $\left(S_{y} \rightarrow Q\right)$ by definition, because the subsidiary object $y$ does not change in the interval of time necessary for specifying this action. The only possible condition is that the state of $y$ is put equal to the class $Q$. Thus we 
have:

F10. V (qtr. incom.): $\left[\mathrm{dS}_{\mathrm{x}}, \mathrm{S}_{\mathrm{y}}, \mathrm{Q},\left(\mathrm{S}_{\mathrm{y}}=\mathrm{Q}\right) \cdot \mathrm{K}\right]$

Such is the case with verba nominandi:

E7. Похвалився оканьний нарекоша его зинець земли.

"The accursed boast of and called it pupil of the Earth." (1. Nov. Chr.).

E8. и зовут я Tamapb, а инии глаголють Таумены, а друзии Печенизи.

"... and they call them Tartars and some name (them) Taumens and still others Pechenegs. (Laur. Chr.).

$\S 15$. If we substitute a constant for the notion $Q$ of $\mathbf{F 1 0}$, we have causatives like ръдъти, бълъти еtс..

The semantic description of these verbs will be:

F11. V (tr. caus.): $\left[\mathrm{dS}_{\mathrm{x}}, \mathrm{dS}_{\mathrm{y}},\left(\mathrm{S}_{\mathrm{y}} \rightarrow q\right) \cdot \mathrm{K}\right]$

As is evident from the formula, this kind of causatives is nothing but the transitive counterpart of inchoatives.

\section{FUNCTION OF THE INSTRUMENTAL CASE}

$\S 16$. It is well known, that in the history of the Russian language these "second" nominatives and accusatives gradually went to decay and were finally substituted by so called "predicative instrumentals" (творительный предикативный) .

To explain this phenomenon, it would be necessary to consider the function of the instrumental case in general, which we did in a different paper.)

There we gave following definition of the instrumental case in Russian as a working hypothesis:

D3. The instrumental case is a form which denotes functioning of the object expressed by a given noun.

The aim of that article was to prove the validity of this hypothesis by materials drawn from documents of the Russian language. The result obtained seems to be almost satisfactory. But we will not discuss this problem here;

6. I. Yamaguchi: The Function of the Instrumental Case in Russian. Forthcoming. 
this brief mention should suffice to explain why the so-called "second" nominatives and accusatives must be substituted by "predicative" instrumentals.

\section{SUBSTITUTION OF INSTRUMENTALS FOR NOMINATIVE AND ACCUSATIVE COMPLEMENTS}

§ 17. Accusative complements of verba fiendi, nominandi, capiendi etc., were, as is already stated, gradually substituted by instrumentals. In relation to substantives used as complements, this process is said to have been completed by the 18 th century. For example,

E9. Отпусти ю, нарекъ ю диерью собъ.

" . . . and he let her go, calling her his daughter." (Laur. Chr.).

E10. Того же лъта поставиша Семеона епископомъ Володимерю. "In the same year, they appointed Semeon as the bishop of Volodimer" (Hyp. Chr.).

E11. Слышю же се, яко сестру имата onвою.

"I hear, that you have a sister unmarried" (Laur. Chr.).

$\S 18$. Let us consider expressions with double objects like "поя ю собъ жену (duxit eam sibi uxorem). In this case pronoun ю "her" denotes a certain real object in the situation of the utterance, while the object denoted by the word жену "wife" has not any objective reality: it only denotes a notion into which "her" state was to be changed as a result of the action поя "he took".

§ 19. That the second accusative complement жену denotes an abstract notion finds support in the fact that the expression like поя ю жену is changed into взял ее в жены with accusative plural of the noun.

Thus two accusative complements followed by an incomplete transitive verb are found to be of quite a different nature in respect to their designata. Such discrepancy in character between two kinds of complements seems to have been constantly felt, consciously or unconsciously, in the language intuition of the Russian speaking people.

It may be reasonable to consider that the reason why complements in the instrumental case came to be used instead of the former second accusatives 
consists in an effort to eliminate this discrepancy.

$\S 20$. If this conjecture is true, another question may arise: why such discrepancy could be eliminated by means of putting nouns in the instrumental?

To answer this question, it may be necessary to examine relations existing between notion and real-object denoted by each of the two accusatives.

A real object $\mathrm{z}$, which is denoted by a given word in the accusative case can be considered as an element belonging to a certain notion (or class) $\mathrm{Q}$, denoted by the other complement. In other words, $z$ is a representative of the class $Q$.

From a somewhat different point of view, $\mathrm{Q}(\mathrm{z})$ can be interpreted as a function of the argument $z$, because we can establish correspondence between each element of a set $\left\{z_{i} / i \in N\right\}$ and that of $\left\{Q_{i} / i \in N\right\}$. That is, we can make $z_{1}, z_{2}$ etc. correspond to $Q_{1}, Q_{2}$ etc..

If this is true, a notion or class would be more adequately expressed by means of a noun in the instrumental case, the grammatical meaning of which is to express, by the assumption D3 given above, functioning of the object denoted by a noun. If, however, $\mathrm{Q}(\mathrm{z})$ is felt to be not so compact owing to the relatively higher degree of individuality of its constituents, it may be more appropriate to indicate it by a noun in the plural. In our conception, such are the cases with nouns denoting a person, his profession, etc.. For example, взять кого в жены, выдвинуть кого в офицеры, отдать кого в горничные еtс..

$\S 21$. Thus, the semantic structure of incomplete transitive verbs followed by an instrumental complement can be described as follows:

F12. $\mathrm{V}_{\mathrm{i}}$ (tr. incom.): $\left[\mathrm{dS}_{\mathrm{x}}, \mathrm{dS} \mathrm{y}, \mathrm{F}(\mathrm{y}),\left(\mathrm{S}_{\mathrm{y}} \rightarrow \mathrm{F}(\mathrm{z})\right) \cdot \mathrm{K}\right]$

Similarly, meanings of incomplete quasitransitive and intransitive verbs are described by the formulae:

F13. $V_{\text {i }}\left(\right.$ qtr. incom.): $\left[\mathrm{dS}_{\mathrm{x}}, \mathrm{S}_{\mathrm{y}}, \mathrm{F}(\mathrm{z}),\left(\mathrm{S}_{\mathrm{y}}=\mathrm{F}(\mathrm{z})\right) \cdot \mathrm{K}\right]$

F14. $V_{i}$ (itr. incom.): $\left[d S_{x}, F(y),\left(S_{x} \rightarrow F(y)\right) \cdot K\right]$

It becomes clear from $\mathbf{F} 14$ why the second accusatives accompanied by verba fiendi showed especially strong tendency to be substituted by predicative instruments: it is in this case that the discrepancy between the function of $y$ and that of $F(y)$ is felt particularly strong owing to the uniqueness of the object, on which the speaker's attention is focused at the moment of 
perceiving an action. For example,

E12. Съгна отца съ престола и самъ царемь ста.

"He expelled his father from the throne and he himself became the tsar" (1. Novg. Chr.).

$\S 22$. The semantic structure of stative verbs is already given above by the Formula 4. Hence, taking into account the above discussions, the semantic structure of incomplete stative verbs would be:

F15. V (itr. stat. incom.): $\left[S_{x}, P,\left(S_{x}=P\right) \cdot\left(S_{x}\left(t_{0}\right)=S_{x}\left(t_{1}\right)\right) \cdot K\right]$

If $\mathrm{K}$ is put equal to zero, we have a semantic description of the copulative verb:

F16. $V($ cop. $):\left[S_{x}, P,\left(S_{x}=P\right) \cdot\left(S_{x}\left(t_{0}\right)=S_{x}\left(t_{1}\right)\right)\right]$

Because $\left(S_{x}=P\right)$ can be interpreted as $(x \in P)$ and as a special case of $\left(S_{x} \subseteq P\right)$, this formula well conforms to Aristotelian logic concerning the structure of a proposition with a copula.

The meaning denoted by F16 is realizable in its pure form only in the present tense, while in other tenses a nuance of change in state is often added.

It is very probable, therefore, that because of these circumstances the present forms of the copulative verb gradually ceased to be used in Russian except when an emphasis is laid on the equality of $S_{x}$ to $P$.

But if we know or believe, that the condition $\left(S_{x}=P\right)$ in the past holds good even at the moment of speech, we cannot say, for example, ${ }^{*}$ Пушкин был великим поэтом instead of Пушкин был великий поэт.

The case is somewhat different with the future tense. Here the condition $\left(S_{x}=P\right)$ always implies that the condition does not exist at the moment of speech, and, therefore, the whole meaning of the verb becomes similar to that of verba fiendi.

These circumstances seem to account for fact that nominative complements are rarely used in Modern Russian with the copulative verb in future tense.

The same is true in imperative and subjunctive moods.

\section{MEANING OF THE COPULATIVE VERB}

$\S 23$. As it is evident from the above observation, the semantic structure of 
the copulative verb followed by predicative instrumentals is found to have two variations: one appears mainly in the past and the other in tenses other than the present. Both have a characteristic trait in common, that they are similar to the semantic structure of verba fiendi.

If we denote the former as $V_{i}^{\prime}$ (cop.) and the latter as $V_{i}^{\prime \prime}(c o p$.), they will be described as follows:

F17! $V_{i}$ (cop.): $\left[d S_{x}, F(y),\left(S_{x}\left(t_{0}\right)=F(y)\right) \cdot\left(S_{x}\left(t_{0}\right) \neq S_{x}\left(t_{1}\right)\right)\right]$

F18.' $V_{i}^{\prime \prime}\left(\right.$ cop.): $\left[\mathrm{d} \mathrm{S}_{\mathrm{x}}, \mathrm{F}(\mathrm{y}),\left(\mathrm{S}_{\mathrm{x}} \rightarrow \mathrm{F}(\mathrm{y})\right)\right]$

Rewriting these formulae so that they may have parallel expressions, we have:

F17. $V_{\mathrm{i}}^{\prime}(\operatorname{cop}):.\left[\mathrm{dS}_{\mathrm{x}}, \mathrm{F}(\mathrm{y}),\left(\mathrm{S}_{\mathrm{x}}\left(\mathrm{t}_{\mathrm{o}}\right)=\mathrm{F}(\mathrm{y})\right)\right]$

F18. $V_{i}^{\prime \prime}$ (cop.): $\left[d S_{x}, F(y),\left(S_{x}\left(t_{1}\right)=F(y)\right)\right]$

Thus it becomes evident that we are dealing here with a case in which a lexical meaning itself is affected directly by the grammatical meanings of tenses.

Uniting F17 and F18 into one, we have:

F19. $V_{i}$ (cop.): $\left[S_{x}, P,\left(\left(S_{x}\left(t_{0}\right)=F(y)\right) \vee\left(S_{x}\left(t_{1}\right)=(F(y))\right)\right]\right.$

On the other hand, F16 can be rewritten as follows:

F20. $V_{n}($ cop. $):\left[S_{x}, P,\left(\left(S_{x}\left(t_{0}\right)=P\right) \wedge\left(S_{x}\left(t_{1}\right)=P\right)\right)\right]$

$\S 24$. We have discussed in another paper that the meaning of a verbum existentiae быть can be considered as:

F21. V (esse): $\left[S_{x}, L,\left(S_{x} \subseteq L\right) \cdot\left(S_{x}\left(t_{0}\right)=S_{x}\left(t_{1}\right)\right) \cdot K\right]$

where $\mathrm{L}$ denotes a certain place. By $\mathrm{S}_{\mathrm{x}} \subseteq \mathrm{L}$ we mean, that $\mathrm{S}_{\mathrm{x}}$ is included in $L$, i.e. in other words, $x$ belongs to $L$ as its constituent. In most of the IndoEuropean languages the set of additional conditions can be considered empty, i.e. $\mathrm{K}=\phi$ (Though this is not the case with Japanese, where ARU "to be" used for inanimate beings is distinguished from its animate counterpart IRU)?

When we substitute a notion $\mathrm{P}$ for $\mathrm{L}$ in $\mathbf{F} 21$, the resulting formula would be:

F22. $\mathrm{V}$ : $\left[\mathrm{S}_{\mathrm{x}}, \mathrm{P},\left(\mathrm{S}_{\mathrm{x}} \subseteq \mathrm{P}\right) \cdot\left(\mathrm{S}_{\mathrm{x}}\left(\mathrm{t}_{\mathrm{0}}\right)=\mathrm{S}_{\mathrm{x}}\left(\mathrm{t}_{1}\right)\right)\right]$

This is precisely the semantic structure of the copulative verb in its more general form mentioned above in $\$ 22$.

7. I. Yamaguchi: On the Meaning of Existential Sentences. Gengo-Kenkyu, Journal of the Linguistic Society of Japan. No.75, 1979, pp.1-30. 
This fact seems to support validity of our argument, because in most European languages the copula is derived from verbum existentiae.

\section{CONCLUSION}

We have provided formulae for semantic structures of some of the most important types of verbs, starting from a fundamental hypothesis concerning meanings of parts of speech in general and those of verbs in particular.

This description has peculiarities which can be summarized as follows:

1. The description is made from the epistemological, or rather, phenomenological point of view.

2. The use of the concepts like actor, patient etc., which are not strictly definable, is avoided.

3. The description shows that at least the main information about the syntactic construction in which a given verb is used is concealed in the very meaning of the verb.

The meaning of verbs is described as consisting of several heterogeneous constituents. Hence it may be incorrect to attribute to the meaning such features as tanimate etc., without regard to what constituent the given features can be ascribed to.

The problem of interference of grammatical meanings in lexical meanings is left undiscussed and still awaits a solution.

\section{BIBLIOGRAPHY}

1. АНСССР: Грамматика Русского Языка. М., 1960.

2. АНСССР: Очерки по исторической грамматике русского литературного языка XIX. 1-5, М., 1964.

3. АНСССР: Словарь современного русского литературного языка в 17 томах. М. -Л., 1950-1965.

4. АНСССР: Сравнительно-исторический синтаксис восточнославянских языков. Члены предложения. Типы простого предложения. М., 1968. 
5. Обратный словарь русского языка. М., 1974.

6. Бондарко, А. В.: Грамматическая Категория и Контекст. Л., 1971.

7. Борковский, В. И., Кузнецов, П. С.: Историческая грамматика русского языка. М., 1963.

8. Булаховский, Л. А.: Исторический комментарий к русскому литературному языку. Киев, 1958.

9. Виноградов, В. В.: Русский язык. (Грамматическое учение о слове). М., 1972.

10. Гвоздев, А. Н.: Современный русский литературный язык. 1, 2. M., 1973.

11. Георгиева, В. Л.: История синтаксических явлений русского языка. М., 1968.

12. Иванов, В. В.: Развитие грамматического строя русского языка. M., 1960.

13. Ломтев, Т. П.: Очерк по историческому синтаксису русского языка. МГУ, 1956.

14. Miklosich, F.: Vergleichende Grammatik der Slavischen Sprachen. Bd. 4, Syntax, Heidelberg, 1926.

15. Мучник, И. П.: Грамматические категории глагола и имени в сов ременном русском литературном языке. М., 1971 .

16. Никитевич, В. М.: Грамматические категории в современном русском языке. М., 1963.

17. Перельмутер, И. А.: Общеиндоевропейский и греческий глагол. Л., 1977.

18. Потебня, А.: Из записок по русской грамматике, Т. 1-2, М. 1958. т. 3, М., 1968, т. 4, 1977.

19. Ревзин, И. И.: Метод моделирования и типология славянских языков. М., 1967.

20. Ревзин, И. И.: Современная структурная лингвистика. М., 1977.

21. Степанов, Ю. С.: Методы и принципы современной лингвистики, M., 1975.

22. Стеценко, А. Н.: Исторический синтаксис русского языка. М., 1977.

23. Суник, О. П.: Общая теория частей речи. М., 1966. 


\section{IWAO YAMAGUCHI}

24. Супрун, А. Е.: Части речи в русском языке. М., 1971.

25. Черных, П. Я.: Историческая грамматика русского языка. М., 1954.

26. Vaillant, F.: Grammaire comparée des langues slaves. t.V. La syntax. Paris, 1977. 